\title{
Biological soil crusts in a changing world: introduction to the special issue
}

\author{
Leopoldo G. Sancho $•$ Fernando T. Maestre $\cdot$ Burkhard Büdel
}

Received: 12 May 2014/ Accepted: 14 May 2014/Published online: 31 May 2014

(C) Springer Science+Business Media Dordrecht 2014

Soil surface communities comprised of cyanobacteria, mosses, liverworts, fungi, eukaryotic algae and lichens (biological soil crusts or biocrusts) are a conspicuous and important biotic component of many terrestrial ecosystems worldwide, from the tropics to the poles, in which they strongly influence ecosystem structure and processes (Belnap and Lange 2003). Biocrusts show the resistance and resilience of life under extreme conditions as well as a remarkable adaptation to the combinations of different climatic factors throughout all latitudes. As such, it is not surprising that multiple aspects of the biology and taxonomy of biocrust constituents have been studied for many years (Belnap and Lange 2003). However, the interest of the scientific community in biocrusts has grown exponentially over the last two decades, and a new wave of research on the ecological roles of biocrusts has been conducted during this period (e.g. Lindo and Gonzalez 2010; Castillo-Monroy and Maestre 2011; Maestre et al. 2011; Mager and Thomas 2011; Pointing and Belnap 2012; Bu et al. 2013 for recent reviews). Research on all aspects of biocrust biology and their influence on ecosystems, traditionally performed by researchers in a few countries, such as the USA, Australia, Israel, and Germany has become a truly global research endeavor, with the emergence of many groups in countries such as China, Spain, and Mexico (CastilloMonroy and Maestre 2011).

The biocrust research community is more interconnected than ever before, as evidenced by the multiple collaborations that are being established among the different groups, by the ongoing preparation of a new book on the status of the field featuring authors from all the

L. G. Sancho $(\bowtie)$

Departamento de Biología Vegetal II, Facultad de Farmacia, Universidad Complutense, 28040 Madrid, Spain

e-mail: sancholg@ucm.es

F. T. Maestre

Área de Biodiversidad y Conservación, Departamento de Biología y Geología, Escuela Superior de Ciencias Experimentales y Tecnología, Universidad Rey Juan Carlos, 28933 Móstoles, Spain

B. Büdel

Plant Ecology and Systematics, Biology, University of Kaiserslautern, Erwin-Schrödinger-Str. 13, 67663 Kaiserslautern, Germany 
continents (Weber et al. 2014), and by the recent establishment of an international series of conferences focusing on biocrusts. The second of these conferences, "Second International Workshop on Biological Soil Cruts: Biological Soil Crusts in a Changing World (Biocrust 2013)" took place in Madrid on 10-13 June 2013. This meeting brought together over 100 researchers from all the continents, who shared during 3 days the results of the most recent research on this ecosystem, and had the opportunity to discuss the status of basic and applied research on biocrusts, and further to start new research initiatives and collaborations to further develop this field further. This special issue includes 13 reviews and primary research articles that derive from communications presented at the Biocrust 2013 conference, and that reflect the wide variety of topics that biocrust researchers are studying worldwide.

The amount of information on biocrusts and their effects on ecosystems currently available has recently fostered their use to test ecological theories, particularly at community and ecosystem levels (see Bowker et al. 2010a; Maestre et al. 2012 for examples). In the first article of this issue, Bowker et al. (2014) review how biocrusts can be used as a model system in community, landscape, and ecosystem ecology. These authors discuss the main features of biocrusts that make them such a useful model system to study multiple topics in these disciplines, and exemplify how the use of biocrusts in this way can provide novel insights and refine existing theory.

Büdel et al. (2014) present the European research initiative "Soil Crust International" (SCIN; http://www.soil-crust-international.org/), a project focusing on the biodiversity of biocrusts and on functional aspects in their specific environments in four sites located along a wide European gradient (Tabernas, Spain; Hochtor-Großglockner, Austria; Gynge Alvar, Sweden; and Homburg, Germany). In this article, the authors present some preliminary results from the project, which already point out the importance of protecting biocrusts and the development of appropriate ways to manage the biodiversity of these communities along the latitudinal and altitudinal gradient studied.

While biocrusts can be found in almost any terrestrial environment where vegetation does not cover $100 \%$ of the soil surface, they are particularly prevalent in arid, semi-arid and dry-subhumid environments (drylands hereafter), which cover $41 \%$ of terrestrial surface and are the home to $38 \%$ of the global population (Safirel and Adeel 2005). Pointing and Belnap (2014) review regional-scale impacts arising from the disturbance of dryland soils and the biocrust communities living on them. They identify the causes of disturbance, emphasize the mobilization of dust to the atmosphere as a major driver of these impacts, and discuss the negative environmental consequences for terrestrial and marine ecosystems, including potential threats to biotic communities and human health.

Major efforts of biocrust researchers have traditionally been devoted to understanding their role in controlling soil and wind erosion (e.g. Eldridge and Greene 1994; Belnap and Gillette 1998; Bowker et al. 2008), and to study the factors influencing the hydrological behavior of biocrusts (e.g. Belnap 2006; Eldridge et al. 2010; Rodríguez-Caballero et al. 2013). Two articles in this issue deal with these topics. Zhao et al. (2014) evaluate the response of biocrusts of different successional stages to raindrop erosivity in the northern Shaanxi province of China. Despite the large number of studies on this topic, research separating the multiple mechanisms of erosion control by biocrusts has been limited. These authors found that biocrusts dramatically improved the resistance of the soil to erosion, and that the biocrust effect varied with both biocrust species composition and the successional stage. Their results suggest that the influence of biocrusts can be incorporated into erosion models. The microstructure of the soil underneath biocrusts is one of the factors affecting their hydrological behavior (Belnap 2006). Felde et al. (2014) investigated the change of 
the pore system of three different successional stages of biocrusts in the NW Negev Desert (Israel) to describe the influence of the soil microstructure of biocrusts on water redistribution. They reported that the pore system undergoes significant changes during crust succession; total porosity, as well as the pore sizes significantly increased from cyanobacteria- to lichen- and moss-dominated biocrusts, and the pore geometry changed from tortuous to straight pore shapes throughout this succession. The authors conclude that the influences of the structural properties of biocrusts must be considered to a much greater extent when investigating their hydrological behavior.

While diversity assessments of above-ground biocrust constituents, like mosses, liverworts, and lichens, have been conducted for many years (e.g. Crespo 1973; Büdel et al. 2009; Buschardt 1979; Eldridge and Tozer 1996; Gutiérrez and Casares 1994; Rogers 2006), researchers have recently started to explore the diversity of microorganisms associated to biocrusts (e.g. Bates et al. 2010; Castillo-Monroy et al. 2011; Liu et al. 2013; Steven et al. 2013). Two articles of this special issue deal with this topic. Elliot et al. (2014) characterized the bacterial communities of biocrusts $(0-1 \mathrm{~cm}$ depth) and the subsurface soil (1-2 cm depth) in the Kalahari Desert (southwest Botswana) using a high throughput $16 \mathrm{~S}$ ribosomal RNA gene sequencing approach. They found that biocrust bacterial communities were distinct with respect to vegetation type and soil depth, and varied in relation to soil carbon, nitrogen, and surface temperature. Cyanobacteria were predominant in the grass interspaces at the soil surface $(0-1 \mathrm{~cm})$ but rare in subsurface soils (1-2 cm depth) and under the shrubs and trees. Bacteroidetes were significantly more abundant in surface soils of all areas even in the absence of a consolidated crust, whilst subsurface soils yielded more sequences affiliated to Acidobacteria, Actinobacteria, Chloroflexi, and Firmicutes. Maier et al. (2014) present a description of the prokaryotic communities found in biocrusts formed by Psora decipiens and Toninia sedifolia in the Tabernas basin (Almería, SE Spain) using 454 high throughput 16S ribosomal RNA gene sequencing approach. As found by Elliot et al. (2014), cyanobacteria were more abundant at the soil surface but rare in below-crust soils, whilst below-crust soils harbored significantly more Acidobacteria, Verrucomicrobia, Gemmatimonadetes, Planctomycetes, and Armatimonadetes. Additionally, Maier et al. (2014) found that bacteria were mainly present at the upper cortex of the lichen squamules and attachment organs, in what represents an interesting fungal-bacterial interaction that merits further research.

Biodiversity research with biocrusts has not been limited to the study of the taxonomic richness of their constituents, and an increasing number of researchers are focusing on other important aspects of biocrust diversity. Unlike the situation with their vascular counterparts, we know little about the diversity of ecological processes in biocrusts, despite its potential to improve our understanding of the maintenance of these ecosystems (Bowker et al. 2010b; Cornelissen et al. 2007). To contribute to this gap, Concostrina et al. (2014) characterized five functional traits for 31 lichens species along a rainfall gradient in Spain. They also evaluated the influence of large scale (i.e. precipitation) and small scale factors (i.e. substrate type, vegetation presence) on the functional diversity of biocrust communities. The authors found multiple trait shifts and a general increase of functional divergence with increasing precipitation. They also observed that substrate type and small scale biotic factors determined shifts in all traits studied, while these factors did not affect functional divergence as much. These findings suggest that the trait composition of biocrust communities is influenced by multi-scale abiotic and biotic factors, with environmental filtering dominating traits at large spatial scales and limiting similarity at small scales. Ruprecht et al. (2014) studied the genetic diversity of green algal partners (photobionts, chlorobionts) in the biocrust-forming lichen $P$. decipiens along four 
European sites of the SCIN project. Using phylogenetic analyses based on molecular data, they found a high chlorobiont diversity within $P$. decipiens, which was associated with several different species of Trebouxia and Asterochloris. Most of the chlorobiont species appeared to be cosmopolitan, but five clades were unevenly distributed between the sampling sites. The wide range of chlorobiont species observed might contribute to the observed abundance of $P$. decipiens in areas widely differing in their environmental conditions and geographical location, such as a semi-arid shrubland in Spain and an alpine site in the Austrian Alps.

The impacts of climate change on biocrust constituents and the ecological processes associated with them are being increasingly studied (Escolar et al. 2012; Maphangwa et al. 2012; Zelikova et al. 2012; Reed et al. 2012; Maestre et al. 2010, 2013). Ladrón de Guevara et al. (2014) adds to this growing, but still scarce, body of literature. These authors report results from a manipulative full factorial experiment conducted in central (Aranjuez) and southeastern (Sorbas) Spain aiming to evaluate how precipitation, temperature, and biocrust cover, affect the assimilation and net $\mathrm{C}$ balance of biocrusts. They found that warming reduced the fixation of atmospheric $\mathrm{C}$ in biocrust-dominated microsites throughout the year in Sorbas. In Aranjuez, there was an interaction between the three factors: during winter, net photosynthesis was significantly greater in high biocrust cover plots under natural conditions than in the rainfall exclusion treatment. The authors also noted the importance of rainfall and non-rainfall water inputs (NRWI) on responses to the climate change treatments they employed. This work suggests that changes in NRWI regimes as consequence of global warming could have a greater impact on the carbon balance of biocrusts than changes in rainfall amounts. They also indicate that climate change may reduce the photosynthetic ability of lichens, with a consequent possible reduction of their dominance in biocrust communities in the mid- to long term.

Raggio et al. (2014) also evaluated results from the simultaneous monitoring of gas exchange, chlorophyll fluorescence, and microclimatic variables, of the most abundant biocrust constituents (the lichens Squamarina cartilaginea, Diploschistes diacapsis, Toninia albilabra and P. decipiens, and the moss Didymodon rigidulus) in the Tabernas badlands (Almeria, SE Spain). Measurements during typical activity days in the field over 1 year showed a similar physiological performance of the different biocrust constituent types studied. They were active under suboptimal conditions, and the duration of activity did not different whether measured by chlorophyll a fluorescence or $\mathrm{CO}_{2}$ gas exchange. These results open the door for the use of continuous chlorophyll a fluorescence measurements, which are becoming increasingly available (e.g. Pintado et al. 2010; Büdel et al. 2014), to estimate the productivity of biocrusts, an important process that, however, is difficult to measure in the field (Raggio et al. 2014).

The last two articles of this special issue are devoted to two key biocrust constituents: cyanobacteria and green algae. Williams et al. (2014) studied how cyanobacteria responded to rehydration during the dry season in the Boodjamulla National Park (Australia). They found that cyanobacteria did not recover PSII activity or $\mathrm{CO}_{2}$ uptake after a rehydratation following a 125 day drought in 2009. Although new colonies of Nostoc grew, other cyanobacteria remained inactive, even though liverworts and lichens in the same biocrust community had responded within $24 \mathrm{~h}$. The authors also collected cyanobacterial crusts during the dry season in 2010, then reintroduced them into their natural environment and exposed to rainfall during the 2011 wet season. Within $24 \mathrm{~h}$, PSII in cyanobacteria from a range of crust types had resurrected, and their $\mathrm{CO}_{2}$ uptake was verified. These results contrast with the widely accepted view that terrestrial cyanobacteria are drought tolerant and rapidly recommence photosynthesis once moisture is available, 
and indicate that cyanobacterial function appears to be controlled by environmental conditions other than rainfall during the dry season. In the last article in this special issue, Karsten and Holzinger (2014) review the acclimation strategies against ultraviolet radiation and dehydration of green algae, which is a major component of biocrusts, particularly in alpine habitats. These organisms serve as good model organisms to study desiccation tolerance or photoprotective mechanisms, due to their natural capacity to withstand unfavorable conditions. The authors point out the urgent need for modern phylogenetic approaches in characterizing these organisms, and molecular methods for analyzing the metabolic changes involved in their adaptive strategies.

Due to the large number of topics being investigated by biocrust researchers, this special issue cannot provide a complete, definitive overview of this body of research. Each of the topics treated in the different articles included would certainly require a special issue by itself, and some, such as the effects of biocrusts on nitrogen cycling (e.g. Belnap 2002; Barger et al. 2005; Delgado-Baquerizo et al. 2010, 2013; Hu et al. 2014), are underrepresented here due to limitations of space. The diverse contributions included in this theme issue are, however, timely and we hope that they will advance our understanding of the important ecological roles played by biocrusts in the ecosystems where they are present, stimulate further research on these important organisms, and increase the awareness of conservationists to the importance of these systems.

Acknowledgments We thank all participants and sponsors (Geónica S. A. and Heinz Walz GmbH) for their support of the Biocrust 2013 conference, and the Facultad de Farmacia from the Universidad Complutense de Madrid for the facilities given to celebrate this meeting. FTM is supported by the European Research Council under the European Community's Seventh Framework Programme (FP7/2007-2013)/ERC Grant agreement no 242658 (BIOCOM). Spanish grants CTM2012-3822-C01-02 and PRI-PIMPDV-20110874 contributed to the organization of this meeting.

\section{References}

Barger NN, Belnap J, Ojima DS, Mosier A (2005) NO gas loss from biologically crusted soils in Canyonlands National Park, Utah. Biogeochemistry 75:373-391

Bates ST, Nash TH, Sweat KG, Garcia-pichel F (2010) Fungal communities of lichen-dominated biological soil crusts, diversity, relative microbial biomass, and their relationship to disturbance and crust cover. J Arid Environ 74:1192-1199

Belnap J (2002) Nitrogen fixation in biological soil crust from southeast Utah, USA. Biol Fertil Soils $35: 128-135$

Belnap J (2006) The potential roles of biological soil crusts in dryland hydrologic cycles. Hydrol Process 20:3159-3178

Belnap J, Gillette DA (1998) Vulnerability of desert biological soil crusts to wind erosion: the influences of crust development, soil texture, and disturbance. J Arid Environ 39:133-142

Belnap J, Lange OL (eds) (2003) Biological soil crusts: structure, function, and management. Springer, New York

Bowker MA, Belnap J, Chaudhary VB, Johnson NC (2008) Revisiting classic water erosion models in drylands: the strong impact of biological soil crusts. Soil Biol Biochem 9:2309-2316

Bowker MA, Soliveres S, Maestre FT (2010a) Competition increases with abiotic stress and regulates the diversity of biological soil crusts. J Ecol 98:551-560

Bowker MA, Maestre FT, Escolar C (2010b) Biological crusts as a model system for examining the biodiversity-function relationship in soils. Soil Biol Biochem 42:405-417

Bowker MA, Maestre FT, Eldridge DJ et al (2014) Biological soil crusts as a model system in community, landscape and ecosystem ecology. Biodivers Conserv. doi:10.1007/s10531-014-0658-x

Bu C, Wu S, Xie Y, Zhang X (2013) The study of biological soil crusts: hotspots and prospects. Clean 41:899-906 
Büdel B, Darienko T, Deutschewitz K, Dojani S, Friedl T, Mohr KI, Salisch M, Reisser W, Weber B (2009) Southern African biological soil crusts are ubiquitous and highly diverse in drylands, being restricted by rainfall frequency. Microb Ecol 57:229-247

Büdel B, Colesie C, Green TGA et al (2014) Improved appreciation of the functioning and importance of biological soil crusts in Europe: the Soil Crust International Project (SCIN). Biodivers Conserv. doi:10. 1007/s10531-014-0645-2

Buschardt A (1979) Zur Flechtenflora der inneralpinen Trockentäler unter besonderer Berücksichtigung des Vinschgau. Bibltheca Lich 10:1-419

Castillo-Monroy AP, Maestre FT (2011) La costra biológica del suelo: avances recientes en el conocimiento de su estructura y función ecológica. Rev Chil Hist Nat 84:1-21

Castillo-Monroy AP, Bowker MA, Maestre FT et al (2011) Relationships between biological soil crusts, bacterial diversity and abundance, and ecosystem functioning: insights from a semi-arid Mediterranean environment. J Veg Sci 22:165-174

Concostrina L, Pescador DS, Martínez I, Escudero A (2014) Climate and small scale factors determine functional diversity shifts of biological soil crusts in Iberian drylands. Biodivers Conserv. doi:10.1007/ s10531-014-0683-9

Cornelissen JHC, Lang SI, Soudzilovskaia NA, During HJ (2007) Comparative cryptogam ecology: a review of bryophyte and lichen traits that drive biogeochemistry. Ann Bot 99:987-1001

Crespo A (1973) Composición florística de la costra de líquenes del Herniario-Teucrietum pumili de la provincia de Madrid. Anal Inst Bot AJ Cavanilles 30:57-68

Delgado-Baquerizo M, Castillo-Monroy AP, Maestre FT, Gallardo A (2010) Change in the dominance of N forms within a semiarid ecosystem. Soil Biol Biochem 42:376-378

Delgado-Baquerizo M, Maestre FT, Gallardo A (2013) Biological soil crusts increase the resistance of soil nitrogen dynamics to changes in temperatures in a semi-arid ecosystem. Plant Soil 366:35-47

Eldridge DJ, Greene RSB (1994) Assessment of sediment yield by splash erosion on a semi-arid soil with varying cryptogam cover. J Arid Environ 26:221-223

Eldridge DJ, Tozer ME (1996) Distribution and floristics of bryophytes in soil crusts in semi-arid and arid eastern Australia. Aust J Bot 44:223-247

Eldridge D, Bowker MA, Maestre FT et al (2010) Interactive effects of three ecosystem engineers on infiltration in a semi-arid Mediterranean grassland. Ecosystems 13:499-510

Elliot DR, Thomas AD, Hoon SR, Sen R (2014) Niche partitioning of bacterial communities in biological crusts and soils under grasses, shrubs and trees in the Kalahari. Biodivers Conserv. doi:10.1007/ s10531-014-0684-8

Escolar C, Martínez I, Bowker MA, Maestre FT (2012) Warming reduces the growth and diversity of biological soil crusts in a semi-arid environment: implications for ecosystem structure and functioning. Philos Trans R Soc B 367:3087-3099

Felde VJMNL, Peth S, Uteau-Puschmann D, Drahorad S, Felix-Henningsen P (2014) Soil microstructure as an under-explored feature of biological soil crust hydrological properties: case study from the NW Negev Desert. Biodivers Conserv. doi:10.1007/s10531-014-0693-7

Gutiérrez L, Casares M (1994) Flora liquénica de los yesos miocénicos de la provincia de Almería (España). Candollea 48:343-358

Hu R, Wang X, Pan Y, Zhang Y, Zhang H (2014) The response mechanisms of soil N mineralization under biological soil crusts to temperature and moisture in temperate desert regions. Eur J Soil Biol 62:66-73

Karsten U, Holzinger A (2014) Green algae in alpine biological soil crust communities: acclimation strategies against ultraviolet radiation and dehydration. Biodivers Conserv. doi:10.1007/s10531-0140653-2

Ladrón de Guevara M, Lázaro R, Quero JL, Ochoa V, Gozalo B, Berdugo M, Uclés O, Escolar E, Maestre FT (2014) Simulated climate change reduced the capacity of lichen-dominated biocrusts to act as carbon sinks in two semi-arid Mediterranean ecosystems. Biodivers Conserv. doi:10.1007/s10531-014$0681-y$

Lindo Z, Gonzalez A (2010) The Bryosphere: an integral and influential component of the Earth's biosphere. Ecosystems 13:612-627

Liu Y, Li X, Xing Z, Zhao X, Pan Y (2013) Responses of soil microbial biomass and community composition to biological soil crusts in the revegetated areas of the Tengger Desert. Appl Soil Ecol 65:52-59

Maestre FT, Bowker MA, Puche MD, Escolar C, Soliveres S, Mouro S, García-Palacios P, Castillo-Monroy AP, Martínez I, Escudero A (2010) Do biotic interactions modulate ecosystem functioning along abiotic stress gradients? Insights from semi-arid plant and biological soil crust communities. Philos Trans R Soc B 365:2057-2070 
Maestre FT, Bowker MA, Cantón Y et al (2011) Ecology and functional roles of biological soil crusts in semi-arid ecosystems of Spain. J Arid Environ 75:1282-1291

Maestre FT, Castillo-Monroy AP, Bowker MA, Ochoa-Hueso R (2012) Species richness effects on ecosystem multifunctionality depend on evenness, composition, and spatial pattern. J Ecol 100:317-330

Maestre FT, Escolar C, Ladrón de Guevara M et al (2013) Changes in biocrust cover drive carbon cycle responses to climate change in drylands. Glob Change Biol 19:3835-3847

Mager DM, Thomas AD (2011) Extracellular polysaccharides from cyanobacterial soil crusts: a review of their role in dryland soil processes. J Arid Environ 75:91-97

Maier S, Schmidt TSB, Zheng L, Peer T, Wagner V, Grube M (2014) Analyses of dryland biological soil crusts highlight lichens as an important regulator of microbial communities. Biodivers Conserv. doi:10. 1007/s10531-014-0719-1

Maphangwa KW, Musil CF, Raitt L, Zedda L (2012) Experimental climate warming decreases photosynthetic efficiency of lichens in an arid South African ecosystem. Oecologia 169:257-268

Pintado A, Sancho LG, Blanquer JM, Green TGA, Lázaro R (2010) Microclimatic factors and photosynthetic activity of crustose lichens from the semiarid southeast of Spain: long-term measurements for Diploschistes diacapsis. Biblio Lich 105:211-224

Pointing SB, Belnap J (2012) Microbial colonization and controls in dryland systems. Nat Rev Microbiol 10:551-562

Pointing SB, Belnap J (2014) Disturbance to desert soil ecosystems contributes to dust-mediated impacts at regional scales. Biodivers Conserv. doi:10.1007/s10531-014-0690-X

Raggio J, Pintado A, Vivas M, Sancho LG, Büdel B, Colesie C, Weber B, Schroeter B, Lázaro R, Green TGA (2014) Continuous chlorophyll fluorescence, gas exchange and microclimate monitoring in a natural soil crust habitat in Tabernas badlands, Almería, Spain: progressing towards a model to understand productivity. Biodivers Conserv. doi:10.1007/s10531-014-0692-8

Reed SC, Coe KK, Sparks JP et al (2012) Changes to dryland rainfall result in rapid moss mortality and altered soil fertility. Nat Clim Change 2:752-755

Rodríguez-Caballero E, Cantón Y, Chamizo S et al (2013) Soil loss and runoff in semiarid ecosystems: a complex interaction between biological soil crusts, micro-topography and hydrological drivers. Ecosystems 16:529-546

Rogers R (2006) Soil surface lichens on a 15 kilometer climatic gradient in subtropical eastern Australia. Lichenologist 38:565-576

Ruprecht U, Brunauer G, Türk R (2014) High photobiont diversity in the common European soil crust lichen Psora decipiens. Biodivers Conserv. doi:10.1007/s10531-014-0662-1

Safirel U, Adeel Z (2005) Dryland systems. In: Hassan R, Scholes R, Neville A (eds) Ecosystems and human well-being: current state and trends, vol 1. Island Press, Washington, DC, pp 623-662

Steven B, Gallegos-Graves LV, Belnap J, Kuske CR (2013) Dryland soil microbial communities display spatial biogeographic patterns associated with soil depth and soil parent material. FEMS Microbiol Ecol 86:1-13

Weber B, Büdel B, Belnap J (eds) (2014) Biological soil crusts: an organizing principle in drylands. Springer-Verlag, Berlin

Williams WJ, Büdel B, Reichenberger H, Rose N (2014) Cyanobacteria in the Australian northern savannah detect the difference between intermittent dry season and wet season rain. Biodivers Conserv. doi:10. 1007/s10531-014-0713-7

Zelikova TJ, Housman DC, Grote ED, Neher D, Belnap J (2012) Biological soil crusts show limited response to warming but larger response to increased precipitation frequency: implications for soil processes on the Colorado Plateau. Plant Soil 355:265-282

Zhao Y, Qin N, Weber B, Xu M (2014) Response of biological soil crusts to raindrop erosivity and underlying influences in the hilly Loess Plateau region, China. Biodivers Conserv. doi:10.1007/ s10531-014-0680-Z 